\title{
Rantai Nilai Pemasaran Telur Itik di Sentra Peternakan Itik, Kecamatan Gadingrejo, Kabupaten Pringsewu
}

\section{The Marketing Value Chain of Duck Egg in The Central Farm of Duck in Gadingrejo District, Pringsewu Regency}

\author{
Maria Herawati ${ }^{1}$ dan Setiyowati ${ }^{1}$ \\ ${ }^{1}$ Fakultas Peternakan, Universitas Tulang Bawang Lampung. Jl. Gajah Mada No.34 Kotabaru, \\ Bandar Lampung \\ herawatimaria@yahoo.com
}

\begin{abstract}
This research aims to find out the marketing value chain of duck egg in the central farm of duck in Gadingrejo District, Pringsewu Regency, Lampung. The result showed that the highest increase in value added occurs in the farmer because the farmer carry out processing in addition to selling in the form of consumption eggs processing into processed eggs or breeding.
\end{abstract}

Keywords: Duck, egg, marketing, value chain, value added

\section{PENDAHULUAN}

Itik merupakan ternak unggas lokal penghasil telur dan daging. Minat masyarakat untuk mengembangkan itik semakin meningkat yang ditandai dengan semakin meningkatnya jumlah populasi itik secara nasional. Tingginya minat masyarakat terhadap ternak itik karena itik sebagai unggas lokal memiliki kelebihan diantaranya lebih tahan terhadap penyakit sehingga risiko usaha relatif lebih kecil.

Pengembangan usaha agribisnis selain aspek budidaya, juga harus memperhatikan aspek pemasaran. Salah satu kunci keberhasilan dalam usaha adalah pemasaran yang efisien dan efektif. Rantai nilai yang efektif dan efisien merupakan kunci keunggulan kompetitif yang dapat menghasilkan nilai tambah (value added). Kabupaten Pringsewu merupakan salah satu sentra itik terbesar keempat setelah Kabupaten Mesuji, Lampung Timur dan Lampung Tengah (BPS Provinsi Lampung, 2017). Memiliki daerah yang potensial bagi pengembangan ternak itik seperti memiliki luasan lahan sawah yang mencapai 21,64 persen dari seluruh wilayahnya, dan yang menjadi sentra sawah di Kabupaten ini adalah di Kecamatan Gadingrejo. Populasi ternak itik di Kecamatan ini tertinggi dibandingkan dengan kecamatan lainnya yaitu sebanyak 1.648 .000 ekor sehingga kecamatan ini menjadi sentra itik di Kabupaten Pringsewu (BPS Kabupaten Pringsewu, 2017).

Penelitian mengenai rantai nilai pemasaran hasil produk peternakan (telur itik) pada sentra peternakan itik di Kecamatan Gadingrejo, Pringsewu, Lampung belum dilakukan, padahal informasi ini dapat mengukur kinerja lembaga atau pelaku dalam pemasaran. Baik atau tidaknya kinerja pemasaran dilihat dari seberapa besar keseluruhan pelaku pemasaran berkoordinasi untuk menciptakan nilai tambah dan memperkecil biaya. Penelitian ini secara khusus dilakukan untuk menganalisis rantai nilai pemasaran telur itik di salah satu sentra peternakan itik di Kabupaten Pringsewu, Lampung.

\section{MATERI DAN METODE}

Metode penelitian yang digunakan adalah metode desriptif analitis dan teknik pelaksanaannya menggunakan metode survey, yaitu pengambilan sampel atau responden dengan menggunakan pengukuran wawancara dengan menggunakan kuesioner sebagai alat bantu (Singarimbun dan Efendi, 1995). Penelitian ini dilaksanakan di Kecamatan Gadingrejo, Kabupaten Pringsewu, Provinsi Lampung. Pemilihan lokasi dilakukan secara sengaja 
(purposif) dengan pertimbangan bahwa di Kecamatan ini merupakan salah satu sentra itik di Kabupaten Pringsewu. Responden penelitian terdiri dari peternak itik dan responden dalam lembaga pemasaran. Pengambilan responden peternakan diperoleh dari Dinas Peternakan Kabupaten Pringsewu, sedangkan responden lembaga pemasaran ditentukan dengan metode snow ball sampling, yaitu pengambilan sampel atau populasi yang tidak jelas keberadaan anggotanya sampai akhirnya menemukan sumber utama informasi, untuk digali keterangan mengenai keberadaan sampel lain.

Analisis yang digunakan untuk mengetahui rantai nilai pemasaran itik adalah menggunakan analisis rantai nilai (VCA atau Value Chain Analysis). Analisis rantai nilai dapat dipergunakan untuk menentukan pada titik mana dalam rantai nilai tersebut dapat mengurangi biaya atau memberikan nilai tambah bagi semua pihak yang terlibat dalam rantai pemasaran (Andri, 2013). Tahapan dalam analisis rantai nilai pemasaran adalah :

a. Pemetaan rantai nilai pemasaran telur itik (proses distribusi telur itik) mulai dari produsen itik petelur yaitu peternak itik sampai dengan konsumen yaitu dengan mengetahui pola rantai pemasaran beserta lembaga pemasarannya.

b. Analisis rantai nilai (value chain) pemasaran telur itik

Rantai nilai pemasaran telur itik dilihat dari lembaga pemasaran mana yang mendapatkan keuntungan paling banyak yang dilihat dari marjin tiap pelaku dengan laba yang diperoleh. Marjin pemasaran diperoleh dari selisih antara harga ditingkat konsumen dengan produsen. Marjin pemasaran diperoleh dari rumus (Julianto dan Darwanto, 2016) :

Keterangan :

$$
\mathrm{Mp}=\mathrm{P}_{\mathrm{r}}-\mathrm{P}_{\mathrm{f}}
$$

$\mathrm{M}_{\mathrm{p}}=$ Marjin Pemasaran telur itik (Rp/ekor)

$\mathrm{P}_{\mathrm{r}}=$ Harga telur itik di tingkat konsumen (Rp/ekor)

$P_{f}=$ Harga telur itik di tingkat produsen (Rp/ekor)

Menghitung besarnya nilai tambah yang diterima setiap pelaku dilakukan dengan menghitung marjin keuntungan digunakan rumus :

Keterangan :

$$
D_{i j}=H_{j j}-H_{b j}-C_{i j}
$$

$D_{i j}=$ keuntungan lembaga pemasaran ke-j

$\mathrm{H}_{\mathrm{jj}}=$ harga jual lembaga pemasaran

$\mathrm{H}_{\mathrm{bj}}=$ Harga beli lembaga pemasaran ke -j

$\mathrm{C}_{\mathrm{ij}}=$ biaya melakukan fungsi pemasaran ke $-\mathrm{I}$ oleh lembaga pemasaran $\mathrm{ke}-\mathrm{j}$

\section{HASIL DAN PEMBAHASAN}

\section{Keadaan Umum Tempat Penelitian}

Kecamatan Gadingrejo terletak di Kabupaten Pringsewu dengan batas wilayah sebelah Utara berbatasan dengan Kecamatan Negeri Katon dan Kecamatan Sukoharjo, sebelah Selatan berbatasan dengan Kecamatan Way Lima, sebelah Barat dengan Kecamatan Pringsewu dan sebelah Timur berbatasan dengan Kecamatan Gedungtataan Kabupaten Pesawaran. Total luas wilayah Kecamatan Gadingrejo sebesar $85,71 \mathrm{~km}^{2}$ atau sekitar $13,71 \%$ dari total luas Kabupaten Pringsewu

Jumlah penduduk Kecamatan Gadingrejo (BPS Kabupaten Pringsewu, 2018) total berjumlah 73.967 jiwa dengan jumlah penduduk laki-laki 37.981 jiwa dan penduduk perempuan berjumlah 35.986 jiwa, sehingga kepadatan penduduk rata-rata sekitar 863 jiwa/ $\mathrm{km}^{2}$. Jika dibandingkan dengan tahun sebelumnya, maka pertambahan penduduk mengalami pertumbuhan sebesar $1,5 \%$.

Kualitas Sumber Daya Manusia melalui banyaknya partisipasi dan adanya fasilitas dalam bidang pendidikan, baik pada jenjang SD/MI, SMP/MTs dan SMA/SMK/MA merupakan 
salah satu aspek penting dalam pembangunan nasional. Jumlah sekolah untuk jenjang SD/MI baik dari negeri ataupun swasta paling banyak (60 sekolah) dibandingkan dengan jenjang SMP/MTs (13 sekolah) dan SMA/SMK/MA (11 sekolah). Angka partisipasi untuk jenjang SD/MI di Kecamatan Gadingrejo paling tinggi yaitu sebanyak 8.007 murid, sedangkan untuk jenjang selanjutnya cenderung menurun yaitu untuk SMP/MTs (4.008 murid) dan SMA/SMK/MA (1.915 murid).

Kecamatan Gadingrejo memiliki luasan sawah berjumlah $3.637 \mathrm{Ha}$ atau mencapai $41,15 \%$ dari seluruh wilayahnya dan memiliki populasi ternak seperti tertera pada Tabel 1.

Tabel 1. Populasi Ternak di Kecamatan Gadingrejo Tahun 2017

\begin{tabular}{cccccccccc}
\hline \multicolumn{10}{c}{ Jumlah Populasi (ekor) } \\
\hline \multicolumn{7}{c}{ Ternak besar } & \multicolumn{8}{c}{ Ternak Kecil } \\
\hline Sapi & Kerbau & Kuda & Kambing & Domba & Babi & $\begin{array}{c}\text { Ayam } \\
\text { Buras }\end{array}$ & $\begin{array}{c}\text { Ayam } \\
\text { Petelur }\end{array}$ & $\begin{array}{c}\text { Ayam } \\
\text { Pedaging }\end{array}$ & Itik \\
\hline 2.226 & 619 & 12 & 1.373 & 4.900 & 130 & 16.606 & 656.600 & 1.558 .000 & 155.312 \\
\hline
\end{tabular}

Berdasarkan Tabel 1, dapat dilihat bahwa populasi ternak unggas terbesar adalah ayam ras pedaging, kemudian diikuti oleh ayam petelur, itik dan ayam buras.

\section{Rantai Pemasaran Komoditas Telur Itik di Kecamatan Gadingrejo}

Pelaku yang terlibat di dalam rantai pemasaran komoditas telur itik di Kecamatan Gadingrejo. Pringsewu antara lain:

a. Peternak Itik Petelur

Rata-rata peternak itik yang ada di Kecamatan Gadingrejo memiliki jumlah kepemilikan itik yang cukup besar yaitu memiliki populasi lebih dari 1.000 ekor untuk dibudidayakan. Ternak itik yang dibudidayakan oleh peternak merupakan jenis itik mojosari salah satu jenis itik tipe petelur dan silangannya (antara alabio dengan mojosari). Telur yang dikoleksi kemudian disortir atau dipilih untuk masuk ke mesin tetas (pembibitan) untuk menghasilkan DOD atau anakan itik dan sisanya diolah untuk menjadi telur asin. Telur yang dijual untuk telur konsumsi dipasarkan ke pedagang besar (broker) atau ke konsumen langsung dalam hal ini penduduk di lingkungan peternak, sedangkan telur olahan dalam bentuk telur asin dipasarkan ke konsumen langsung, dalam hal ini warung makan atau pengunjung car free day (CFD) di Pringsewu dengan harga jual Rp. 2.750/butir. Bibit itik (DOD) langsung dipasarkan ke konsumen langsung, dalam hal ini peternak itik lainnya dengan harga jual rata-rata sebesar Rp.10.000/ekor. Rata-rata telur konsumsi yang dijual ke pedagang besar sebesar Rp.1.850/butir sedangkan untuk dijual ke lingkungan atau tetangga sekitar sebesar Rp.2.000/butir.

b. Pedagang Besar (broker)

Pedagang besar membeli hasil produksi dari peternak dengan harga rata-rata sebesar Rp. 1.850/butir. Telur yang dibeli dari peternak disortir dan dicuci bersih kemudian dijual kembali dengan harga Rp. 2.200/butir ke pedagang eceran ataupun konsumen rumah tangga dan warung makan. Telur ada yang sebagian diolah oleh pedagang besar apabila terdapat sisa penjualan menjadi telur asin dan dijual ke konsumen dalam hal ini pedagang olahan telur dengan harga Rp.2.400/butir.

c. Pedagang Eceran

Pedagang eceran membeli telur dari pedagang besar dengan harga rata-rata sebesar Rp.2.200/butir. Telur yang telah dibeli disortir kembali dan kemudian dijual ke konsumen dalam hal ini konsumen rumah tangga dengan harga Rp.2.500/butir.

Pola aliran produk komoditas telur itik dapat dilihat pada Gambar 1 berikut ini. 


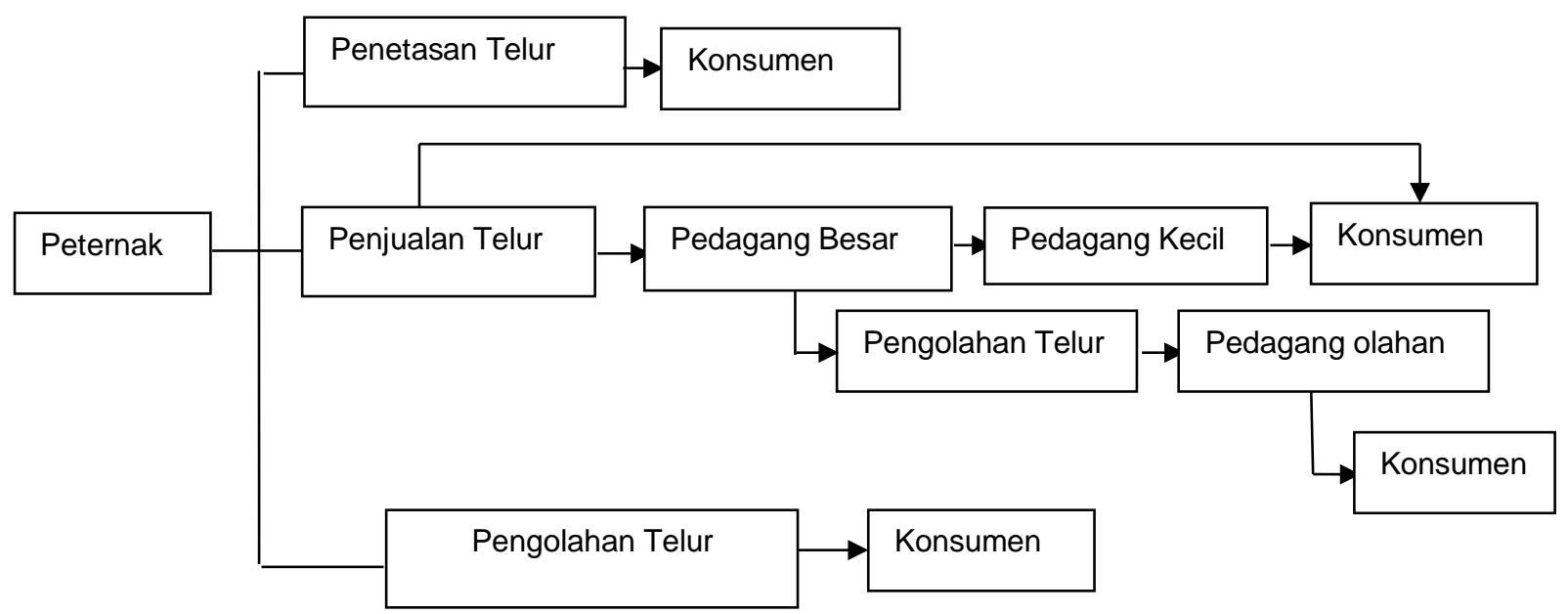

Gambar 1. Aliran Komoditas Telur Itik

Berdasarkan Gambar 1 komoditas telur itik memiliki saluran pemasaran yaitu:

1.Peternak $\rightarrow$ konsumen telur itik

2. Peternak $\rightarrow$ konsumen olahan telur

3. Peternak $\rightarrow$ konsumen DOD

4. Peternak $\rightarrow$ pedagang besar $\rightarrow$ pedagang kecil $\rightarrow$ konsumen telur itik

5. Peternak $\rightarrow$ pedagang besar $\rightarrow$ pedagang olahan telur $\rightarrow$ konsumen olahan telur

Pada saluran pertama rantai pemasaran adalah peternak menghasilkan telur itik konsumsi yang langsung dijual kepada konsumen. Saluran kedua adalah peternak mengolah hasil produksi menjadi telur asin (olahan telur) kemudian menjualnya langsung kepada konsumen. Saluran ketiga adalah peternak menetaskan telur yang kemudian dijual kepada konsumen dalam bentuk anakan itik. Saluran keempat adalah peternak menghasilkan telur itik konsumsi yang dijual kepada pedagang besar (broker telur) yang kemudian dijual kepada pedagang kecil baru kemudian ke konsumen. Saluran kelima adalah peternak menjual hasil produksi kepada pedagang besar, kemudian oleh pedagang besar telur tersebut diolah menjadi telur asin (olahan telur) yang kemudian dijual kepada pedagang olahan telur itik lalu dijual kepada konsumen.

\section{Marjin Pemasaran Komoditas Telur Itik}

Marjin pemasaran diperoleh dari selisih antara harga ditingkat konsumen dengan produsen. Marjin pemasaran komoditas telur itik tersaji pada Tabel 2. 
Tabel 2. Marjin Pemasaran Komoditas Telur Itik

\begin{tabular}{|c|c|c|c|c|c|c|}
\hline Keterangan & $\begin{array}{l}\text { Harga } \\
\text { Beli }\end{array}$ & $\begin{array}{l}\text { Harga } \\
\text { Jual }\end{array}$ & $\begin{array}{c}\text { Marjin } \\
\text { Pemasara } \\
\mathbf{n}\end{array}$ & $\begin{array}{c}\text { Total } \\
\text { Marjin } \\
\text { Pemasaran }\end{array}$ & $\begin{array}{l}\text { Persentase } \\
\text { Marjin } \\
\text { Pemasaran }\end{array}$ & $\begin{array}{c}\text { Persentas } \\
\text { e Farmer's } \\
\text { Share }\end{array}$ \\
\hline \multicolumn{7}{|c|}{ Saluran Pemasaran 1} \\
\hline Peternak (Rp/butir) & $1.045^{\star}$ & 1.850 & 805 & & & \\
\hline $\begin{array}{l}\text { Konsumen telur itik } \\
\text { (Rp/butir) }\end{array}$ & 1.850 & & & & & \\
\hline \multicolumn{7}{|c|}{ Saluran Pemasaran 2} \\
\hline Peternak (Rp/butir) & $2.431^{*}$ & 2.750 & 319 & & & \\
\hline $\begin{array}{l}\text { Konsumen olahan } \\
\text { telur (Rp/butir) }\end{array}$ & 2.750 & & & & & \\
\hline \multicolumn{7}{|c|}{ Saluran Pemasaran 3} \\
\hline Peternak (Rp/ekor) & $4.018^{*}$ & 10.000 & 5.982 & & & \\
\hline $\begin{array}{l}\text { Konsumen DOD } \\
\text { (Rp/ekor) }\end{array}$ & 10.000 & & & & & \\
\hline \multicolumn{7}{|c|}{ Saluran Pemasaran 4} \\
\hline Peternak (Rp/butir) & $1.045^{\star}$ & 1.850 & 805 & & & \\
\hline $\begin{array}{l}\text { Pedagang besar } \\
\text { (Rp/butir) }\end{array}$ & 1.850 & 2.200 & 350 & & & \\
\hline $\begin{array}{l}\text { Pedagang kecil } \\
\text { (Rp/butir) }\end{array}$ & 2.200 & 2.500 & 300 & 1.455 & 58,20 & 41,80 \\
\hline $\begin{array}{l}\text { Konsumen telur itik } \\
\text { (Rp/butir) }\end{array}$ & 2.500 & & & & & \\
\hline \multicolumn{7}{|c|}{ Saluran Pemasaran 5} \\
\hline Peternak (Rp/butir) & $1.045^{\star}$ & 1.850 & 805 & & & \\
\hline $\begin{array}{l}\text { Pedagang besar } \\
\text { (Rp/butir) }\end{array}$ & 1.850 & 2.200 & 350 & & & \\
\hline $\begin{array}{l}\text { Pedagang olahan telur } \\
\text { (Rp/butir) }\end{array}$ & 2.200 & 2.400 & 200 & 1.355 & 56,46 & 43,54 \\
\hline $\begin{array}{l}\text { Konsumen olahan } \\
\text { telur (Rp/butir) }\end{array}$ & 2.400 & & & & & \\
\hline
\end{tabular}

Berdasarkan Tabel 2 dapat diketahui bahwa pada saluran pertama, total marjin pemasaran adalah Rp.805/butir dengan persentase marjin pemasaran sebesar $43,51 \%$. Saluran kedua memiliki total marjin pemasaran sebesar Rp.319/butir dengan persentase marjin pemasaran sebesar Rp.11,6\%. Saluran ketiga memiliki total marjin pemasaran sebesar Rp.5.982/ekor dan persentase marjin sebesar 59,82\%. Saluran keempat marjin pemasaran tertiggi adalah pada peternak yaitu sebesar Rp.805/butir dan terendah pada pedagang kecil yaitu sebesar Rp.300/butir dengan total marjin pemasaran sebesar Rp.1.455/butir dan persentase marjin pemasaran sebesar 58,20\%. Saluran pemasaran kelima, marjin pemasaran tertinggi adalah pada peternak yaitu sebesar Rp.805/butir dan terendah pada pedagang olahan telur yaitu sebesar Rp.200 dengan total marjin pemasaran sebesar Rp.1.355 dan persentase marjin pemasaran sebesar 56,46\%.

Farmer's share adalah besarnya harga yang diterima oleh produsen dibandingkan dengan harga yang diterima oleh konsumen. Semakin tinggi nilai farmer's share maka semakin efisien yang artinya bahwa tingkat harga yang diterima oleh konsumen tidak berbeda jauh dengan yang diterima oleh produsen (Herawati dan Setiyowati, 2019) ${ }^{2}$. Berdasarkan Tabel 6 diperoleh nilai persentase farmer's share pada saluran keempat sebesar 41,80 dan saluran kelima sebesar 43,54. Nilai persentase tersebut menunjukkan bahwa pemasaran komoditas telur itik di Kecamatan Gadingrejo tidak efisien karena nilai persentase farmer's share berkisar $<50 \%$ atau tingkat harga yang diterima oleh konsumen berbeda jauh dengan yang diterima oleh peternak. Nilai farmer's share yang tertinggi adalah pada saluran kelima 
yaitu sebesar $43,54 \%$ kemudian yang terendah adalah pada saluran keempat yaitu sebesar $41,80 \%$, artinya saluran kelima paling efisien dibandingkan dengan saluran lainnya.

\section{Rantai Nilai Pemasaran Telur Itik}

Analisis rantai nilai selanjutnya dilakukan untuk menentukan pada titik-titik mana dalam rantai nilai tersebut yang dapat mengurangi biaya atau memberikan nilai tambah (value added) bagi semua pihak yang terlibat dalam rantai pemasaran komoditas telur itik. Hasil analisis rantai nilai (VCA) komoditas telur itik tersaji pada Tabel 3.

Tabel 3. Analisis rantai nilai (VCA) komoditas telur itik

\begin{tabular}{|c|c|c|c|c|c|c|c|}
\hline \multirow[b]{2}{*}{$\begin{array}{c}\text { Faktor Rantai } \\
\text { Nilai }\end{array}$} & \multicolumn{7}{|c|}{ Pelaku Usaha } \\
\hline & Peternak & $\begin{array}{c}\text { Pedagang } \\
\text { Besar }\end{array}$ & $\begin{array}{c}\text { Pedagang } \\
\text { Kecil }\end{array}$ & $\begin{array}{l}\text { Pedagang } \\
\text { Olahan }\end{array}$ & $\begin{array}{c}\text { Konsumen } \\
\text { telur itik }\end{array}$ & $\begin{array}{c}\text { Konsumen } \\
\text { olahan } \\
\text { telur }\end{array}$ & $\begin{array}{c}\text { Konsumen } \\
\text { DOD }\end{array}$ \\
\hline Harga Beli (Rp) & & 1.850 & 2.200 & 2.200 & $\begin{array}{l}1.850 \\
2.500\end{array}$ & $\begin{array}{l}2.400 \\
2.750\end{array}$ & 10.000 \\
\hline HPP & & & & & & & \\
\hline $\begin{array}{l}\text { a. Budidaya } \\
\text { (Rp/butir) }\end{array}$ & 1.045 & 1.917 & 2.316 & 2.237 & & & \\
\hline $\begin{array}{l}\text { b. Pengolahan } \\
\text { (Rp/butir) }\end{array}$ & 2.431 & 2.190 & - & - & & & \\
\hline $\begin{array}{l}\text { C. Pembibitan } \\
\text { (Rp/ekor) }\end{array}$ & 4.018 & - & - & - & & & \\
\hline Harga Jual & & & & & & & \\
\hline $\begin{array}{ll}\text { a. } & \text { Telur } \\
& \text { (Rp/butir) }\end{array}$ & 1.850 & 2.200 & 2.500 & - & & & \\
\hline $\begin{array}{l}\text { b. Telur } \\
\text { olahan }\end{array}$ & 2.750 & 2.400 & - & 2.500 & & & \\
\hline $\begin{array}{ll}\text { (Rp/butir) } \\
\text { c. } \\
\text { DOD } \\
\text { (Rp/ekor) }\end{array}$ & 10.000 & - & - & - & & & \\
\hline $\begin{array}{l}\text { Marjin Rantai } \\
\text { Nilai (Rp) }\end{array}$ & & & & & & & \\
\hline a. Telur & 805 & 283 & 184 & - & & & \\
\hline b. Telur & 319 & 210 & - & 263 & & & \\
\hline $\begin{array}{ll} & \text { olahan } \\
\text { c. } & \text { DOD }\end{array}$ & 5.982 & - & - & - & & & \\
\hline
\end{tabular}

Hasil analisis rantai nilai dari komoditas telur itik di Kecamatan Gadingrejo (Tabel 2) menunjukkan bahwa peningkatan nilai yang ditambahkan tertinggi terjadi pada pelaku usaha peternak itu sendiri karena peternak melakukan pengolahan selain menjual dalam bentuk telur konsumsi juga mengolah menjadi telur olahan atau melakukan pembibitan itik yang mengakibatkan penambahan nilai sebesar Rp.319/butir untuk telur olahan dan Rp.5.982/ekor untuk pembibitan, sedangkan pelaku lainnya seperti pedagang besar jika hanya menjual telur konsumsi mendapatkan peningkatan nilai tambah sebesar Rp.283/butir, namun jika melakukan kegiatan pengolahan maka akan mendapatkan peningkatan nilai tambah menjadi sebesar Rp.493/butir.

\section{KESIMPULAN}

a. Terdapat 5 macam rantai pemasaran telur itik di daerah sentra peternakan Kecamatan Gadingrejo yaitu saluran pertama (peternak-konsumen telur itik), saluran kedua (peternakkonsumen olahan telur), saluran ketiga (peternak- konsumen DOD), saluran keempat (peternak-pedagang besar-pedagang kecil- konsumen telur itik) dan saluran kelima (peternak-pedagang besar-pedagang olahan telur-konsumen olahan telur).

b. Peningkatan nilai yang ditambahkan tertinggi terjadi pada pelaku usaha peternak itu sendiri karena peternak melakukan pengolahan selain menjual dalam bentuk telur konsumsi juga mengolah menjadi telur olahan atau melakukan pembibitan itik 
DAFTAR PUSTAKA

Andri, K.B. 2013. Analisis Rantai Nilai Pasok dan Rantai Nilai Bunga Krisan di Daerah Sentra Pengembangan Jawa Timur. Jurnal SEPA 10(1) September 2013 Hal 1-10. [30 April 2018].

Badan Pusat Statistik Provinsi Lampung. 2017. Provinsi Lampung Dalam Angka. BPS Provinsi Lampung. Bandar Lampung.

Badan Pusat Statistik Kabupaten Pringsewu. 2017. Kabupaten Pringsewu Dalam Angka. BPS Kabupaten Pringsewu. Pringsewu.

Herawati, M. dan Setiyowati. 2019. Rantai Pemasaran Ayam Kampung Super di Kabupaten Lampung Timur. Jurnal Wahana Peternakan 3(1) Maret 2019 Hal 1-6. [1 Agustus 2019]

Julianto, E.W. dan Darwanto. 2016. Analisis Rantai Nilai (Value Chain) Jagung di Kecamatan Toroh Kabupaten Grobogan. Jurnal JPEB 1 (1) 2016 Hal : 1-15. http://www.jpeb.dinus.ac.id. [30 April 2018].

Singarimbun, M dan Efendi, S. 1995. Metode Penelitian Survei. LP3ES. Jakarta. 